\title{
EFFECTS OF TRICYCLIC ANTIDEPRESSANTS ON TETRABENAZINE-INDUCED DEPLETION OF BRAIN MONOAMINES IN RATS. 1. NOREPINEPHRINE
}

\author{
Toshio YOSHIZAKI and Kanya TONDA \\ Shionogi Research Laboratories, Shionogi \& Co., Lid., \\ Fukushima-ku, Osaka 553, Japan
}

Accepted June 2, 1980

\begin{abstract}
We studied the effects of tricyclic antidepressants on the tetrabenazine (TB)-induced depletion of brain norepinephrine (NE) using rats. The test drugs were generally administered orally $3 \mathrm{hr}$ bcfore and $2 \mathrm{mg} / \mathrm{kg}$ of TB or reserpine (RES) administered subcutancously $2 \mathrm{hr}$ before sacrifice. The TB-induced NE depletion was enhanced by pretreatment with desmethylimipramine (DMI, 25-100 $\mathrm{mg} / \mathrm{kg}$ ), imipramine (IM, 25-100 $\mathrm{mg} / \mathrm{kg}$ ), chlorimipramine $(100 \mathrm{mg} / \mathrm{kg}$ ), maprotyrine $(50 \mathrm{mg} / \mathrm{kg}$ ), amitriptyrine $(50-100 \mathrm{mg} \mathrm{kg})$, chlorpromazine (CPZ, 5-20 $\mathrm{mg} \mathrm{hg}$ i.p.) and amphetamine sulfate $(10 \mathrm{mg} / \mathrm{kg})$. DM! partially suppressed TB-induced NE depletion at $0.5 \mathrm{hr}$ after TB administration. The RES-induced NE depletion was not enhanced with these drugs except for amphetamine. DMI, IM, and CPZ suppressed it instead. DMI also enhanced the yohimbine $(2 \mathrm{mg} / \mathrm{kg}$ )-induced decrease. The brain NE content showed a tendency toward recovery $2 \mathrm{hr}$ after TB administration, but approached the minimal level at $0.5 \mathrm{hr}$ after TB administration or at $2 \mathrm{hr}$ after RES administration in non-treated rats. In pargyline-pretreated rats, TB produced a decrease of brain NE with an increase of normetanephrine, while the action of R.ES was weaker than that of TB, up to 2. hr. These results suggest that enhancement of the TB-induced brain NE depletion by tricyclic antidepressants reffects the blockage of NE reuptake from the synaptic cleft.
\end{abstract}

Tricyclic antidepressants inhibit norepinephrine (NE) reuptake at the neuronal cell membrane and this effect is considered to be an important action mechanism of these drugs (1-4). These drugs also antagonize various pharmacological effects of reserpine (RES) and tetrabenazine (TB) (5-7), and such effects have been used as indicators of the antidepressant action. Although the effect of the antidepressants on RES-induced changes of biogenic amine metabolism has been studied usually with desmethylimipramine (DMI) $(8,9)$, there are few reports in the literature on the TB-induced changes. We studied the acute effects of tricyclic antidepressants on the TB-induced and RES-induced depletion of brain NE and found that they enhance the former but not the latter.

\section{MATERIALS AND METHODS}

Seven-week-old male Sprague-Dawley rats were used. The animals were exsanginated, the brain quickly removed, and the hemisphere which had been placed in acid-butanol or $0.4 \mathrm{~N}$ perchloric acid was homogenized and centrifuged. NE content of the acid-butanol extract was determined by the fluorimetric method of Chang (10) with slight modification and the normetanephrine (NM) content in the perchloric acid extract by the fluorimetric 
method of Karasawa et al. (11).

The drugs used were imipramine hydrochloride (IM, Tofranil ${ }^{\circledR}$ Inj.-Fujisawa), desmethylimipramine hydrochloride (Pertofran ${ }^{\circledR}$ Inj.-Fujisawa), chlorimipramine hydrochloride (CI, Anafranil ${ }^{\circledR}$ Inj.-Fujisawa), maprotyrine hydrochloride (synthetized in the Shionogi Laboratory), amitriptyrine hydrochloride (AT), chlorpromazine hydrochloride (CPZ), DLamphetamine sulfate (Zedrin ${ }^{\circledR}$-Takeda), tetrabenazine (TB, Rubigen ${ }^{\circledR}$ Inj.-Eisai), reserpine (Apoplon ${ }^{\circledR}$ Inj.-Daiichi), pargyline hydrochloride (Regis) and yohimbine hydrochloride (Sigma). The doses except for that of amphetamine were calculated as those of the free bases. IM, DMI, CI, MT, and AT were administered orally and yohimbine by s.c., as solutions or suspensions in $2.5 \%$ gum arabic. Pargyline and CPZ were administered i.p. as $0.9 \%$ saline solutions. RES and diluted TB solution with $0.9 \%$ saline were administered s.c.

The significance of the difference between the means of the response was evaluated by Student's $t$-test.

\section{RESULTS}

\section{Effects of IM and DMI on the TB-induced depletion of brain NE content}

Table 1 shows the effect of IM pretreatment on the TB-induced depletion of the brain NE content. Pretreatment with $100 \mathrm{mg} / \mathrm{kg}$ of IM enhanced the NE depletion induced by $2 \mathrm{mg} / \mathrm{kg} \mathrm{TB}$, but not that induced by $10 \mathrm{mg} / \mathrm{kg}$ TB at $2 \mathrm{hr}$ after TB administration. DMI pretreatment $(50 \mathrm{mg} / \mathrm{kg})$ also enhanced the TB $(2 \mathrm{mg} / \mathrm{kg})$-induced NE depletion at $2 \mathrm{hr}$ after TB administration, but partially suppressed it at $0.5 \mathrm{hr}$, had little effect at $1 \mathrm{hr}$, and enhanced it at $3 \mathrm{hr}$ (not statistically significant) after TB administration (Table 2).

2. Dose studies on the effects of several drugs on TB-and RES-induced depletion of brain NE content

Effects of several drugs on TB- and RES-induced depletion of the brain NE content were studied at $2 \mathrm{hr}$ after administration of $2 \mathrm{mg} / \mathrm{kg}$ of TB or RES. As shown in Table 3, IM and DMI enhanced the TB-induced NE depletion in doses of $25 \mathrm{mg} / \mathrm{kg}$ or more, but

TABLE 1. Effect of imipramine on tetrabenazine-induced depletion of brain norepinephrine in rats

\begin{tabular}{lcc}
\hline Treatment & $\begin{array}{c}\text { No. of } \\
\text { rats }\end{array}$ & $\begin{array}{c}\text { Norepinephrine } \\
(\mu \mathrm{g} / \mathrm{g})\end{array}$ \\
Control & 5 & $0.36 \pm 0.02$ \\
Imipramine & 5 & $0.35 \pm 0.01$ \\
TB 2 & 5 & $0.19 \pm 0.00$ \\
Imipramine + TB 2 & 2 & $0.16 \pm 0.01^{+}$ \\
TB 10 & 5 & $0.08 \pm 0.00$ \\
Imipramine + TB 10 & 5 & $0.08 \pm 0.00$ \\
\hline
\end{tabular}

Imipramine $(100 \mathrm{mg} / \mathrm{kg})$ was administered p.o. $1 \mathrm{hr}$ before tetrabenazine administration and rats were sacrificed $2 \mathrm{hr}$ later. TB 2: Tetrabenazine $2 \mathrm{mg} / \mathrm{kg}$ s.c., TB 10: Tetrabenazine $10 \mathrm{mg} / \mathrm{kg}$. Data represent the mean \pm S.E. † Significantly different from the corresponding tetrabenazine administration $\mathrm{p}<0.05$. 
TABLE 2. Effect of desmethylimipramine pretreatment on tetrabenazine-induced depletion of brain norepinephrine in rats

\begin{tabular}{ccc}
\hline $\begin{array}{c}\text { Time after tetrabenazine } \\
\text { administration (hr) }\end{array}$ & \multicolumn{2}{c}{ Norepinephrine $(\mu \mathrm{g} / \mathrm{g})$} \\
Control & $0.35 \pm 0.01(6)$ & \\
2.0 & $0.19 \pm 0.00(6)$ & $0.15 \pm 0.01(6)^{\dagger}$ \\
Control & $0.37 \pm 0.02(4)$ & \\
0.5 & $0.20 \pm 0.01(6)$ & $0.25 \pm 0.02(5)^{*}$ \\
1.0 & $0.19 \pm 0.01(6)$ & $0.21 \pm 0.01(5)$ \\
3.0 & $0.23 \pm 0.01(6)$ & $0.20 \pm 0.01(5)$ \\
\hline
\end{tabular}

Desmethylimipramine (DMI, $50 \mathrm{mg} / \mathrm{kg}$ p.o.) was administered at $3 \mathrm{hr}$ and tetrabenazine $(2 \mathrm{mg} / \mathrm{kg}$ s.c.) at $0.5,1.0,2.0$ or $3.0 \mathrm{hr}$ before sacrifice. Data represent the mean S.E. The number of rats is given in parentheses. †, *Significantly different from the corresponding tetrabenazine administration $\mathrm{p}<0.01$.

partially suppressed the RES-induced depletion at doses of $12.5 \mathrm{mg} / \mathrm{kg}$ or more, except at $25 \mathrm{mg} / \mathrm{kg}$. Enhancement of the TB-induced NE depletion was also observed with CI (100 $\mathrm{mg} / \mathrm{kg}$ ), AT (50-100 mg/kg), MT (50 mg/kg), and CPZ (5-20 mg/kg i.p.). CPZ reduced the RES-induced NE depletion, while CI, AT and MT had no effect. Amphetamine enhanced both depletions.

Effects of the highest doses of tested drugs on the brain NE level were also studied $3 \mathrm{hr}$ after drug administration. No change of the NE level was observed with IM, DMI, MT and CPZ. CI, AT and amphetamine produced a slight decrease in the NE levels (daia not shown).

\section{Comparative effects of TB and RES on brain NE content}

To elucidate the differential effects of antidepressants on TB- and RES-induced NE depletion, the following studies were performed. First, we compared the effect of TB on the brain NE content with that of RES at doses of $2 \mathrm{mg} / \mathrm{kg}$. As shown in Fig. 1, after administration of $\mathrm{TB}$, the brain NE content sharply decreased within $0.5 \mathrm{hr}$, then decreased gradually until a minimal level was reached at $1 \mathrm{hr}$, after which a gradual return to the control

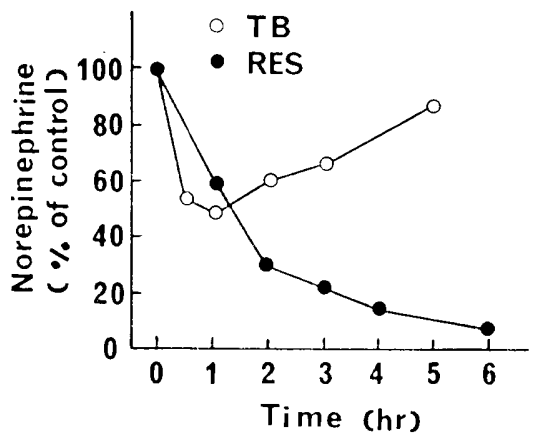

FIG. 1. Changes in the brain levels of norepinephrine after administration of tetrabenazine ( $\mathrm{TB}, 2 \mathrm{mg} / \mathrm{kg}$ s.c.) and reserpine (RES, $2 \mathrm{mg} / \mathrm{kg}$ s.c.) in rats. Each point represents the mean of 6 determinations. 
TABLE 3. Effects of several drugs on tetrabenazine- and reserpine-induced depletion of brain norepinephrine in rats

\begin{tabular}{|c|c|c|c|c|}
\hline \multirow{2}{*}{$\begin{array}{l}\text { Treatment } \\
(\mathrm{mg} / \mathrm{kg})\end{array}$} & & & \multicolumn{2}{|c|}{ Norepinephrine $(\mu \mathrm{g} / \mathrm{g})$} \\
\hline & & Tetrabenazine & Reserpine \\
\hline Control & & & $0.35 \pm 0.012(6)$ & $0.37 \div 0.017(6)$ \\
\hline Depletor (D) & & & $0.19 \pm 0.005$ & $0.11 \pm 0.006(7)$ \\
\hline \multirow[t]{4}{*}{ Desmethylimipramine } & & $5+D$ & $0.19 \div 0.010(6)$ & $0.15 \leq 0.010(6)^{* *}$ \\
\hline & 25 & $\div \mathrm{D}$ & $0.17 \pm 0.005(6)^{\dagger}$ & $0.12 \pm 0.008$ \\
\hline & 50 & $+\mathrm{D}$ & $0.15 \div 0.007(6)^{t}$ & $0.15=0.007(6)^{* *}$ \\
\hline & 100 & $+\mathrm{D}$ & $0.15 \div 0.005(6)^{*}$ & $0.16 \pm 0.010(6)^{* *}$ \\
\hline Control & & & $0 . \overline{33} \doteq 0.007(6)$ & $0.39 \pm 0.017(6)$ \\
\hline Depletor (D) & & & $0.18=0.005(6)$ & $0.13 \pm 0.006(6)$ \\
\hline \multirow[t]{4}{*}{ Imipramine } & & $5 \cdot D$ & $0.160 .012(6)$ & $0.18 \pm 0.008(6)^{* * *}$ \\
\hline & & $+D$ & $0.16 \div 0.007(6)^{\dagger}$ & $0.15+0.008(6)$ \\
\hline & 50 & $+\mathrm{D}$ & $0.16 \pm 0.009(6)$ & $0.16=0.006(6)^{* * *}$ \\
\hline & 100 & $+\mathrm{D}$ & $0.15 \div 0.005(6)$ & $0.17 \div 0.013(6)^{* * *}$ \\
\hline Control & & & $0.34 \pm 0.007(5)$ & $0.35-0.010(6)$ \\
\hline Depletor (D) & & & $0.19 \div 0.008(6)$ & $0.11=0.009(6)$ \\
\hline \multirow[t]{4}{*}{ Chlorimipramine } & & $5 \div D$ & $0.18 \div 0.009$ (6) & $0.13=0.006(6)$ \\
\hline & & $\mathrm{D}$ & $0.17 \pm 0.007(6)$ & $0.12 \pm 0.007(6)$ \\
\hline & 50 & $D$ & $0.17: 0.009(6)$ & $0.11 \pm 0.006(6)$ \\
\hline & 100 & $+\mathrm{D}$ & $0.16 \div 0.002(6)^{\dagger}$ & $0.13 \div 0.007(6)$ \\
\hline Control & & & $0.34 \therefore 0.009(6)$ & $0.29 \pm 0.007(6)$ \\
\hline Depletor (D) & & & $0.18 \div 0.005(7)$ & $0.10 \pm 0.009(6)$ \\
\hline \multirow[t]{4}{*}{ Amitriptyline } & & 5:D & $0.18 \div 0.007(6)$ & \\
\hline & & $+\mathrm{D}$ & $0.17 \pm 0.004(6)$ & $0.09 \pm 0.006(6)$ \\
\hline & & $+\mathrm{D}$ & $0.16 \pm 0.006(6)^{\dagger}$ & $0.12 \pm 0.005(6)$ \\
\hline & 100 & $+\mathrm{D}$ & $0.16 \pm 0.005(6)^{\dagger}$ & $0.11 \div 0.006(6)$ \\
\hline Control & & & $0.34 \pm 0.009$ (6) & $0.32 \div 0.008(6)$ \\
\hline Depletor (D) & & & $0.20-0.006(5)$ & $0.12=0.008(6)$ \\
\hline \multirow[t]{4}{*}{ Maprotyrine } & & $5 \div D$ & $0.18 \pm 0.008(6)$ & $0.11 \pm 0.005(6)$ \\
\hline & & $D$ & $0.18 \div 0.004(6)$ & $0.13 \pm 0.009(6)$ \\
\hline & 50 & $+\mathrm{D}$ & $0.16-0.003(6)$ & $0.13 \pm 0.008(6)$ \\
\hline & 100 & $+\mathrm{D}$ & & $0.13 \div 0.006(6)$ \\
\hline Control & & & $0.35+0.014(5)$ & $0.36 \pm 0.011(6)$ \\
\hline Depletor (D) & & & 0.180 .004 (5) & $0.11 \leq 0.008(6)$ \\
\hline \multirow[t]{2}{*}{ Chlorpromazine } & 5 & $D$ & $0.14 \pm 0.004(5)$ & \\
\hline & 20 & $+\mathrm{D}$ & $0.14 \perp 0.009(5)$ & $0.15-0.008(6)^{* * *}$ \\
\hline Control & & & $0.37-0.014$ & $0.34 \pm 0.0 .007$ (6) \\
\hline Depletor (D) & & & $0.16+0.006$ & $0.13 \pm 0.005$ \\
\hline \multirow[t]{3}{*}{ Amphetamine } & 2 & $\mathrm{D}$ & $0.14 \div 0.007(6)$ & $0.12 \pm 0.015$ (6) \\
\hline & 5 & $D$ & & $0.09 \pm 0.006(6)^{\ddagger}$ \\
\hline & 10 & $\mathrm{D}$ & $0.13 \div 0.002(5)^{\dagger}$ & $0.09 \pm 0.012(6)^{\dagger}$ \\
\hline
\end{tabular}

Drugs (except chlorpromazine, i.p.) were administered p.o. 1 hr before tetrabenazine ( $2 \mathrm{mg} / \mathrm{kg}$ s.c.) or reserpine ( $2 \mathrm{mg} / \mathrm{kg}$ s.c.) administration and rats were sacrificed $2 \mathrm{hr}$ later. Data represent the mean S.E. The number of rats is given in parentheses. † Significantly different from the corresponding depletor administration $\mathrm{p}<0.05$. $\ddagger$,**Significantly different from the corresponding depletor administration $\mathrm{p}<0.01$. 

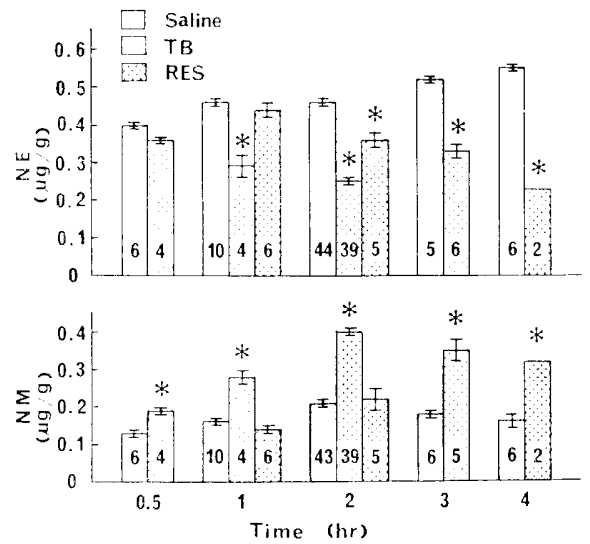

Fig. 2. Effects of tetrabenazine (TB) and reserpine (RES) on the brain levels of norepinephrine (NE) and normetanephrine (NM) in pargyline-pretreated rats. Pargyline $(150 \mathrm{mg} / \mathrm{kg}$ i.p.) was administered $1 \mathrm{hr}$ before administration of TB ( $2 \mathrm{mg} / \mathrm{kg} \mathrm{s.c.)}$ or RES ( $2 \mathrm{mg} / \mathrm{kg} \mathrm{s.c.).} \mathrm{Bars} \mathrm{are} \mathrm{S.E.} \mathrm{of} \mathrm{the} \mathrm{mean.} \mathrm{Numbers} \mathrm{in}$ the columns indicate the number of determinations. *Significantly different from the corresponding saline administration $\mathrm{p}<0.01$.

level was seen. However, after administration of RES, brain NE depletion decreased, neared the minimal level after $4 \mathrm{hr}$, then continued at this level.

In rats in which the brain monoamine oxidase (MAO) activity was almost completely inhibited by pretreatment with $150 \mathrm{mg} / \mathrm{kg}$ of pargyline, TB produced a decrease in the brain NE content with an increase of normetanephrine (NM), up to $3 \mathrm{hr}$. However, RES induced only a slight decrease of NE with no change of NM, up to $2 \mathrm{hr}$, but did produce changes at $4 \mathrm{hr}$ which were similar to those seen at $2 \mathrm{hr}$ after TB administration (Fig. 2).

\section{Effect of DMI pretreatment on the yohimbine-induced decrease of brain NE content}

We then attempted to determine whether NE reuptake inhibition would produce a decrease of NE under the conditions of hypersecretion to the synaptosomal cleft, using DMI and yohimbine. As shown in Table 4, the brain NE content slightly decreased $2 \mathrm{hr}$ after s.c.

TABle 4. Effect of desmethylimipramine on yohimbine-induced decrease of brain norepinephrine $\mathrm{in}_{\mathrm{i}}$ rats

\begin{tabular}{|c|c|c|}
\hline $\begin{array}{l}\text { Treatment } \\
(\mathrm{mg} / \mathrm{kg})\end{array}$ & $\begin{array}{l}\text { No. of } \\
\text { rats }\end{array}$ & $\begin{array}{c}\text { Norepinephrine } \\
(\mu \mathrm{g} / \mathrm{g})\end{array}$ \\
\hline Control & 6 & $0.35 \pm 0.01$ \\
\hline Yohimbine $(\mathrm{Y})$ & 7 & $0.30 \div 0.01$ \\
\hline DMI $\quad 12.5 \cdot+\mathrm{Y}$ & 6 & $0.26 \pm 0.01^{\dagger}$ \\
\hline DMI $25 \quad+$ Y & 6 & $0.25 \pm 0.01 \dagger$ \\
\hline DMI $50 \quad+\mathrm{Y}$ & 6 & $0.25 \pm 0.01^{\dagger}$ \\
\hline DMI $100 \quad-+\mathrm{Y}$ & 6 & $0.25 \perp 0.01^{\dagger}$ \\
\hline
\end{tabular}

Desmethylimipramine (DMI) was administered p.o. $1 \mathrm{hr}$ before s.c. administration of yohimbine $(2 \mathrm{mg} / \mathrm{kg}$ ) and rats were sacrificed $2 \mathrm{hr}$ later. Data represent the mean $\pm \mathrm{S}$.E. †Significantly different from yohimbine administration $\mathrm{p}<0.01$. 
TABLE 5. Effects of imipramine, desmethylimipramine and chlorpromazine on reserpineinduced changes of brain levels of norepinephrine and normetanephrine in pargylinepretreated rats

\begin{tabular}{lccc}
\hline Treatment & $\begin{array}{c}\text { No. of } \\
\text { rats }\end{array}$ & $\begin{array}{c}\text { Norepinephrine } \\
(\mu \mathrm{g} / \mathrm{g})\end{array}$ & $\begin{array}{c}\text { Normetanephrine } \\
(\mu \mathrm{g} / \mathrm{g})\end{array}$ \\
\hline Control & 6 & $0.35 \pm 0.01$ & $0.02 \pm 0.00$ \\
Pargyline (Par) & 7 & $0.44 \pm 0.01$ & $0.20 \pm 0.01$ \\
Par + CPZ & 8 & $0.36 \pm 0.01$ & $0.37 \pm 0.01$ \\
Par + RES & 7 & $0.35 \pm 0.02$ & $0.26 \pm 0.01$ \\
Par + CPZ + RES & 8 & $0.29 \pm 0.01^{\dagger}$ & $0.33 \pm 0.03$ \\
\hline Par & 6 & $0.48 \pm 0.02$ & $0.26 \pm 0.02$ \\
Par + IM & 6 & $0.47 \pm 0.02$ & $0.27 \pm 0.01$ \\
Par + DMI & 6 & $0.45 \pm 0.02$ & $0.21 \pm 0.01$ \\
Par + RES & 6 & $0.28 \pm 0.02$ & $0.35 \pm 0.02$ \\
Par + IM + RES & 6 & $0.36 \pm 0.02^{*}$ & $0.28 \pm 0.02^{\dagger}$ \\
Par + DMI + RES & 6 & $0.33 \pm 0.01$ & $0.28 \pm 0.01 \dagger$ \\
\hline
\end{tabular}

Pretreatment with pargyline $(150 \mathrm{mg} / \mathrm{kg})$ was given $1 \mathrm{hr}$ before, and with imipramine (IM, $100 \mathrm{mg} / \mathrm{kg}$ p.o.), desmethylimipramine (DMI, $100 \mathrm{mg} / \mathrm{kg}$ p.o.) and chlorpromazine (CPZ, $20 \mathrm{mg} / \mathrm{kg}$ i.p.) $45 \mathrm{~min}$ before administration of reserpine (RES, $2 \mathrm{mg} / \mathrm{kg}$ s.c.) and the animals were sacrificed $2 \mathrm{hr}$ later. Data represent the mean \pm S.E. $\dagger,{ }^{*}$ Significantly different from pargyline plus reserpine administration $p<0.05$.

administration of $2 \mathrm{mg} / \mathrm{kg}$ of yohimbine and this decrease was enhanced by pretreatment with DMI at $12.5 \mathrm{mg} / \mathrm{kg}$ or more.

5. Effects of IM, DMI and CPZ on the RES-induced decrease of brain NE in pargylinepretreated rats

To clarify the action mechanisms of IM, DMI and CPZ in the reduction of the RESinduced decrease of brain NE, experiments were performed using rats in which the brain MAO activity was almost completely inhibited by parglyine pretreatment. As shown in Table 5, IM and DMI also suppressed the RES-induced NE decrease with an increase of $\mathrm{NM}$ in pargyline-pretreated rats, while CPZ enhanced these RES-induced changes.

\section{DISCUSSION}

RES and TB, which are monoamine-depleting agents, exert similar biochemical effects on catecholamine (CA) stores by blocking the mechanism of amine storage granules (12). Although the action mechanisms of these two agents are generally considered identical, tricyclic antidepressants enhanced the TB-induced NE depletion but not the RES-induced depletion. DMI, IM and CPZ tended to suppress the RES-induced depletion, as was also observed by other researchers $(8,13)$. In our experiments, the brain NE contents were usually determined $2 \mathrm{hr}$ after the administration of $2 \mathrm{mg} / \mathrm{kg}$ of the depleting agents. At that time, the brain NE content was recovering from its TB-induced reduction to a minimal level. This shows that the mechanism of the amine storage granules had fairly recovered from the TB effect. In the case of RES, the amine storage mechanism remained blocked as the brain NE content approached a minimal level. TB caused a faster decrease in NE 
and increase in NM than RES in rats in which brain MAO activity was almost completely inhibited by pargyline treatment. This shows that $\mathrm{TB}$ has a stronger effect than RES on NE release to the synaptic cleft until $2 \mathrm{hr}$. As TB has no effect on the neuronal cell membrane, this release is probably due to diffusion from the cell. Tricyclic antidepressants inhibit NE reuptake from the presynaptic cell membrane and also affect the mechanism of NE storage granules $(14,15)$. Therefore, enhancenent of TB-induced NE depletion with tricyclic antidepressants reflects their blockage of NE reuptake, while inhibition of RESinduced NE depletion with DMI, IM and CPZ pretreatment could be explained by their prevention of RES-induced blockage of the storage granule mechanism. This was supported by the findings that DMI suppressed NE depletion at $0.5 \mathrm{hr}$ after TB administration when TB had a fairly strong effect on the storage granules.

DMI and IM also suppressed the RES-induced NE decrease with an increase of NM in pargyline-pretreated rats, while CPZ enhanced these changes. This suppression can also be explained by their prevention of RES-induced blockage of the storage granule mechanism. As CPZ has an adrenergic blocking effect $(16,17)$, NE secretion was probably enhanced through a negative feedback control mechanism and the NE releasing action may have exceeded the suppression of NE decrease by its protection against the effect of RES on the granules.

Yohimbine blocks presynaptic receptors, causing hypersecretion of $\mathrm{NE}(18,19)$. In our study, DMI enhanced the yohimbine-induced decrease of brain NE content, thereby providing evidence that inhibition of NE reuptake under hypersecretion of NE results in a decrease in NE content, and also supports the hypothesis that enhancement of TB-induced NE depletion strongly reflects a blockage of NE reuptake. DMI reduces the firing rate of central NE which is probably mediated through a negative feedback mechanism $(20,21)$ and yohimbine blocks the inhibition by DMI (21). Therefore, our findings that the doses of DMI causing enhancement of the yohimbine-induced NE decrease were lower than those causing enhancement of the TB-induced depletion probably resulted from blockage of the DMI-induced inhibition of NE neurons by yohimbine.

CPZ, an antipsychotic drug, also enhanced the TB-induced NE depletion, and thus blocked NE reuptake. A similar suggestion had been made by other researchers regarding the uptake of labeled NE in peripheral tissues (22) and in the brain $(1,23)$. However, as $\mathrm{CPZ}$ is an adrenergic blocking agent $(16,17)$, the possibility remains that the enhancement of TB-induced NE depletion increases with hypersecretion of NE.

Amphetamine, which accelerates NE release and blocks NE reuptake (24), enhanced both TB- and RES-induced NE depletion, unlike CPZ and tricyclic antidepressants.

Methods for studying blockage of NE reuptake include inhibition of labeled NE accumulation in tissues from the incubation medium using tissue slices (25) or homogenates (26) and inhibition of the accumulation of administered labeled NE in organ tissues in vivo $(3,23)$. As NE accumulates in the NE storage granules within neuronal cells (27), the actual amount of indicator measured in these methods is thought to be that of the labeled NE in the storage granules. Other in vivo methods involved the inhibition of the NE depletion 
induced by $\alpha$-methyl-m-tyramine derivatives (28) or guanethidine (29) in the brain or heart. These agents enter the NE storage granules, expel the endogenous NE and deplete the tissue NE content (30). Therefore, it is difficult to distinguish the inhibition of NE reuptake of the cell membrane from the inhibition of NE uptake into the storage granules. The decrease of metaraminol accumulated by adrenergic neurons caused by TB in rats pretreated with antidepressants is said to reflect inhibition of NE reuptake by the cell membrane (31). However, although the mechanism of metaraminol reuptake is similar to that of NE, it is not identical. In contrast with these methods, our results showing enhancement of TBinduced NE depletion reflect a fairly selective inhibition of NE reuptake from the synaptic cleft.

We conclude that tricyclic antidepressants enhance the TB-induced NE depletion at $2 \mathrm{hr}$ after administration of $2 \mathrm{mg} / \mathrm{kg}$ of $\mathrm{TB}$, thereby reflecting the fairly selective inhibition of NE reuptake from the synaptic cleft.

\section{REFERENCES}

1) Dengler, H.J., Spiegfl, H.e. and Titus, E.O.: Effects of drugs on uptake of isotopic norepinephrinc by cat tissues. Nature 191, 816-817 (1961)

2) Titus, E.O. And Spifgre, H.E.: Effect of desmethyl-imipramine (DMI) on uptake of nor-

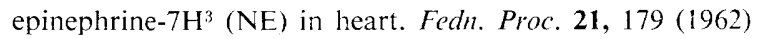

3) Glowinski, J. AND AXElRoD, J.: Inhibition of uptake of tritiated-noradrenaline in the intact rat brain by imipramine and structurally related compounds. Nature 204, $1318-1319(1964)$

4) Glowinski, J., AXelrod, J. ANd IVersfen, L.L.: Regional studies of catecholamines in the rat brain. IV. Effects of drugs on the disposition and metabolism of $\mathrm{H}^{3}$-norepinephrine and $\mathrm{H}^{3}$-dopamine. J. Pharmacol. exp. Ther. 153, 30-4l (1966)

5) Sulsfr, F., Watts, J. And Brodif, B.B.: On the mechanism of antidepressant action of imipraminelike drugs. Ann. N.Y. Acad. Sci. 96, 279-288 (1962)

6) Garattini, S., Giachetti, A., Jori, A. and Valzelli, L.: Effect of imipramine, amitriptyline and their monomethyl derivatives on reserpine activity. J. Pharm. Pharmacol. 14, 509-514 (1962)

7) Ross, S.B. AND RenYI, A.L.: Inhibition of the uptake of tritiated catecholamines by antidepressant and related agents. Europ. J. Pharmacol. 2, 181-186 (1967)

8) Manard, L., Sestini, M.G., Algeri, S. and Garattini, S.: On the ability of desipramine to interfere with reserpine-induced noradrenaline release. J. Pharm. Pharmacol. 18, 194-195 (1966)

9) Roffler-Tarlov, S.: Differences between the effects of acute and long-term treatment with desmethylimipramine on reserpine-induced release of amines from rat brain. Biochem. Pharmacol. 24, 1321-1325 (1975)

10) CHANG, C.C.: A sensitive method for spectrophotofluorometric assay of catecholamines. Int. J. Neuropharmacol. 3, 643-649 (1964)

11) Karasawa, T., Furukawa, K., Yoshida, K. and Siimizu, M.: A double column procedure for the simultancous estimation of norepinephrine, normetanephrine, dopamine, 3-methoxytyramine and 5-hydroxytryptamine in brain tissue. Japan. J. Pharmacol. 25, 727-736 (1975)

12) Quinn, G.P., Shore, P.A. And Brodie, B.B.: Biochemical and pharmacological studies of RO 1-9569 (Tetrabenazine), a non-indole tranquilizing agent with reserpine-like effects. J. Pharmacol. exp. Ther. 127, 103-109 (1959)

13) Gey, K.F. And Pletscher, A.: Influence of chlorpromazine and chlorprothixene on the cerebral metabolism of 5-hydroxytryptamine, norepinephrine and dopamine. J. Pharmacol. exp. Ther. 133, 18-24 (1961) 
14) Brodie, B.B., Costa, E., Groppetti, A. And Matsumoto, C.: Interaction between desipramine, tyramine, and amphetamine at adrenergic neurones. Brit. J. Pharmacol. 34, 648-658 (1968)

15) Steinberg, M.I. And Smith, C.B.: Effects of desmethyl-imipramine and cocaine on the uptake, retention and metabolism of $\mathrm{H}^{3}$-tyramine in rat brain slices. J. Pharmacol. exp. Ther. 173, 176-192 (1970)

16) Webster, R.A.: The antiadrenaline activity of some phenothiazine derivatives. Brit. $J$. Pharmacol. 25, 566-576(1965)

17) Gokhale, S.D., Gulati, O.D. And Parikh, H.M.: An investigation of the adrenergic blocking action of chlorpromazine. Brit. J. Pharmacol. 23, 508-520 (1964)

18) Anden, N.-E., Grabowska, M. and Strömbom, U.: Different alpha-adrenoreceptors in the central nervous system mediating biochemical and functional effects of clonidine and receptor blocking agents. Naunyn-Schmiedeberg's Arch. Pharmacol. 292, 43-52 (1976)

19) Anden, N.-E. and Grabowska, M.: Pharmacological evidence for a stimulation of dopamine neurons by noradrenaline neurons in the brain. Europ. J. Pharmacol. 39, 275-282 (1976)

20) Nybäck, H.V., Walters, J.R., Aghajanian, G.K. and Roth, R.H.: Tricyclic antidepressants: Effects on the firing rate of brain noradrenergic neurons. Europ. J. Pharmacol. 32, 302-312 (1975)

21) Svensson, T.H. AND Usdin, T.: Feedback inhibition of brain noradrenaline neurons by tricyclic antidepressants: $\alpha$-Receptor mediation. Science 202, 1089-1091 (1978)

22) Axelrod, J., Whiby, L.G. and Hertting, G.: Effect of psychotropic drugs on the uptake of $\mathrm{H}^{3}$-norepinephrine by tissues. Science 133, 383-384 (1961)

23) Schanberg, S.M., Schildkraut, J.J. and Kopin, I.J.: The effects of psychoactive drugs on norepinephrine- ${ }^{3} \mathrm{H}$ metabolism in brain. Biochem. Pharmacol. 16, 393-399 (1967)

24) Glowinski, J. ANd Axelrod, J.: Effect of drugs on the uptake, release and metabolism of $\mathrm{H}^{3}$-norepinephrine in the rat brain. J. Pharmacol. exp. Ther. 149, 43-49 (1965)

25) Dengler, J.J., Michaelson, I.A., Spiegel, H.E. and Titus, E.: The uptake of labeled norepinephrine by isolated brain and other tissues of the cat. Int. J. Neuropharmacol. 1, 23-38 (1962)

26) SNyder, S.H. AND COYLE, J.T.: Regional differences in $\mathrm{H}^{3}$-norepinephrine and $\mathrm{H}^{3}$-dopamine uptake into rat brain homogenates. J. Pharmacol. exp. Ther. 165, 78-86 (1969)

27) Axelrod, J.: Noradrenaline: Fate and control of its biosynthesis. Science 173, 598-606 (1971)

28) Carlsson, A., Corrodi, H., Fuxe, K. and Hökfelt, T.: Effect of some antidepressant drugs on the depletion of intraneuronal brain catecholamine stores caused by $4, \alpha$-dimethylmeta-tyramine. Europ. J. Pharmacol. 5, 367-373 (1969)

29) Maitre, L., Staehelin, M. and Bein, H.J.: Blockade of noradrenaline uptake by 34276-Ba, a new antidepressant drug. Biochem. Pharmacol. 20, 2169-2186 (1971)

30) Maitre, L. and Staehelin, M.: Guanethidine uptake and noradrenaline depletion in noradrenaline storage particles of the rat heart. Biochem. Pharmacol. 20, 1233-1242 (1971)

31) Murad, J.E. and Shore, P.A.: Association between biochemical and behavioral actions of tricyclic antidepressants. Int. J. Neuropharmacol. 5, 299-304 (1966) 